\title{
Why Whistleblowers Lose: An Empirical and Qualitative Analysis of State Court Cases
}

\author{
Nancy M. Modesitt*
}

\section{INTRODUCTION}

This Article was originally intended to be an analysis of the propriety, or impropriety, of the doctrines most commonly used by courts to decide employees' whistleblowing retaliation claims against employers. However, upon conducting initial research, it quickly became apparent that there was very little data available on whistleblowing cases. Unlike employment discrimination cases, where several empirical studies have been conducted, there is only one empirical analysis of whistleblower claims, which focused solely on outcomes in the federal administrative process for claims brought under the Sarbanes-Oxley Act $(\mathrm{SOX}) .{ }^{1}$ That study revealed that whistleblowers fare poorly for a number of reasons, but many of the reasons suggested by the author appear to be unique to SOX plaintiffs. ${ }^{2}$ This Article studies the success rates of whistleblowers suing under state law, as different a context as possible from SOX, and identifies common reasons whistleblower claims fail in these cases.

\section{PeRsPectives ON WhistLeblowers}

Legal protections for whistleblowers are a fairly recent

\footnotetext{
* Associate Professor of Law, University of Baltimore School of Law. I would like to thank Penny Pether for her ceaseless support and willingness to read drafts of my work, my research assistants, Erin Creech and Julie Hudnet, and the University of Baltimore for its ongoing support of my research.

1. See Richard E. Moberly, Unfulfilled Expectations: An Empirical Analysis of Why SarbanesOxley Whistleblowers Rarely Win, 49 WM. \& MARY L. REV. 65 (2007) [hereinafter Moberly, Unfulfilled Expectations]. Professor Moberly revisited this study in 2012 and concluded that win rates were still quite low. Richard E. Moberly, Sarbanes-Oxley's Whistleblower Provisions: Ten Years Later, 64 S.C. L. REV. 1 (2012) [hereinafter Moberly, Ten Years Later].

2. See Moberly, Unfulfilled Expectations, supra note 1, at 100-20 (arguing that "procedural hurdles" unique to Sarbanes-Oxley and the limited scope of protection under the act contribute to low whistleblower success rates).
} 
phenomenon. ${ }^{3}$ They have developed over the last century, resulting in a multitude of sources of legal protection for whistleblowers. ${ }^{4}$ More recently, and on a nearly annual basis, Congress has enacted additional protections for whistleblowers. ${ }^{5}$ Research suggests that whistleblowers play an important role in uncovering fraud, with indications that whistleblowers in fact provide some of the most valuable information about corporate fraud. ${ }^{6}$ The current trend of legislative action has been quite supportive of whistleblowers. This support, however, does not mean that whistleblowers are able to report corporate wrongdoing with impunity.

\section{A. Employer and Regulator Responses to Whistleblowing}

Even though there is legislative support for greater whistleblower protections, it does not appear that employers share that sentiment. ${ }^{7}$ While there has been some conflicting evidence regarding the extent of retaliation against whistleblowers under $\mathrm{SOX}^{8}{ }^{8}$ a recent study of whistleblowing in corporations suggests that employees who blow the whistle do not fare well professionally. ${ }^{9}$ This study considered situations where corporate fraud was alleged involving U.S. companies between 1996 and 2004. ${ }^{10}$ Part of the analysis concerned the professional effects of blowing the whistle for individuals who disclosed potential corporate

3. See generally Daniel P. Westman \& NANCY M. ModesitT, WhistLeblowing: The LaW OF RETALIATORY DisChARGE 1-12 (2d ed. 2004) (describing the development of legal protections for whistleblowers in the United States).

4. See id. apps. A-F (2d ed. 2004 \& Supp. 2012) (listing hundreds of sources of legal protections for whistleblowers).

5. See id. at 4-10 to 4-15 (Supp. 2012) (describing new protections such as the Dodd-Frank Act, the National Transit Systems Security Act, the American Recovery and Reinvestment Act, and the Patient Protection and Affordable Health Care Act).

6. See Richard P. Nielsen, Whistle-Blowing Methods for Navigating Within and Helping Reform Regulatory Institutions, 112 J. BuS. ETHICS 385, 385 (2013) ("There is a great deal of evidence to suggest that whistle-blowing is one of the most important sources of information for detecting and reducing illegal and unethical corporate behaviors.") (citing STEPHEN M. KOHN, THE Whistleblower's HANDBOOK: A STEP-By-STEP Guide to DOING What's Right and PROTECTING YOURSELF (2011)).

7. See, e.g., Eugenie Samuel Reich, Whistle-blower Claims His Accusations Cost Him His Job, 474 NATURE 140, 140 (2011) (describing how one researcher was given the choice of voluntarily resigning or being fired after he raised concerns about the accuracy of his supervisor's research).

8. See Moberly, Ten Years Later, supra note 1, at 27-28 (describing varying empirical evidence regarding retaliation against SOX whistleblowers).

9. Alexander Dyck, Adair Morse \& Luigi Zingales, Who Blows the Whistle on Corporate Fraud?, 65 J. FIN. 2213, 2240-45 (2010).

10. Id. at 2213 . 
fraud. ${ }^{11}$ Outsiders fared significantly better than employees. ${ }^{12}$ Journalists, for instance, were more likely to find better jobs after they reported corporate fraud. ${ }^{13}$ In contrast, $82 \%$ of employee whistleblowers reported retaliation in the form of being fired, quitting under duress, or suffering significantly altered employment responsibilities. ${ }^{14}$ Many said, "If I had to do it over again, I wouldn't." ${ }^{15}$ Employees were often forced to change the industry in which they worked and the location in which they lived in order to avoid harassment. ${ }^{16}$

Numerous other researchers have found similar incidents of professional retaliation, ranging from receiving poor performance evaluations all the way up to being blacklisted in an entire industry. ${ }^{17}$ Other studies have found much lower rates of retaliation. For example, the Ethics Resource Center's 2011 study of whistleblowers found that $22 \%$ of employees who reported misconduct suffered retaliation. ${ }^{18}$ While these two studies report widely disparate rates of retaliation, even if the reality is closer to the lower $22 \%$ rate, it means that nearly a quarter of those who report their employer's wrongdoing suffer retaliation.

The prevalence of retaliation in these studies resonates with anecdotal evidence regarding the effects of whistleblowing on employees. C. Fred Alford's book, Whistleblowers: Broken Lives and Organizational Power, details some of the consequences that arise in whistleblowers' personal lives. ${ }^{19}$ The book begins with a whistleblower's description of how his life changed after reporting misconduct: "I didn't just lose my job. I lost my house, and then I lost my family." 20 Similarly, when Roger Boisjoly exposed flaws in the decision to launch the space shuttle Challenger, not only did his career "end[] up in the toilet big time," he also suffered adverse health

11. Id. at $2240-45$.

12. See id. at 2231-48 (concluding employees suffer significantly more than auditors, analysts, and journalists).

13. See id. at $2239-40$.

14. Id. at 2240 .

15. Id. at 2216 .

16. Id. at $2240,2245$.

17. See, e.g., Carmen R. Apaza \& Yongjin Chang, What Makes Whistleblowing Effective: Whistleblowing in Peru and South Korea, 13 PUB. INTEGRITY 113, 116 (2011).

18. 2011 National Business Ethics Survey: Workplace Ethics in Transition, ETHICS RES. CTR. 1, 15 (2012), http://www.ethics.org/nbes/files/FinalNBES-web.pdf.

19. C. Fred Alford, Whistleblowers: Broken Lives And Organizational Power (2001).

20. Id. at 1 . 
consequences, including post-traumatic stress disorder. ${ }^{21}$ Additionally, whistleblowers can suffer financially both due to losing a job from retaliation and costs associated with personal problems such as divorce. ${ }^{22}$

It is not only corporations that react strongly to whistleblowers. Even regulators can fail to react positively to whistleblowers due to political pressure. ${ }^{23}$ Historically, whistleblowers who exposed some of the more egregious conduct of the government have been targeted. ${ }^{24}$ For example, Daniel Ellsberg, who leaked the Pentagon Papers to the press, was prosecuted by the federal government. ${ }^{25}$ Charges were only dropped when it was revealed that government agents had broken into his psychiatrist's office in an attempt to uncover damaging information about him. ${ }^{26}$ Coleen Rowley, who revealed failures within the FBI at uncovering the $9 / 11$ plot, was demoted and pushed out of the agency. ${ }^{27}$ Recently, the Obama Administration has responded to whistleblowing with federal criminal charges of disclosing confidential information. ${ }^{28}$ The Administration even fired a CIA whistleblower's spouse, who also worked for the Agency, after the whistleblower made disclosures to the public about missteps in the War on Terror. ${ }^{29}$ The most recent whistleblower to be targeted by the Administration is Edward J. Snowden, who is the seventh individual indicted for leaking classified information under this Administration. ${ }^{30}$ But perhaps most tellingly, an entire book has been written on how to "survive" being a whistleblower with one full chapter devoted to describing the dangers whistleblowers

21. RoBerta ANn JOHnSOn, WhistLeBLOWING: WHEN IT WORKS-AND Why 36 (2003).

22. See Nielsen, supra note 6 , at 389 (discussing that whistleblowing is frequently associated with adverse career consequences leading to financial difficulty, marital strain, and ultimately divorce).

23. See id. at 386-89 (noting that political actors under pressure can influence appointed regulators to overlook whistleblowing cases).

24. See Lance DeHaven-Smith, Myth and Reality of Whistleblower Protections: Official Behavior at the Top, 13 PUB. INTEGRITY 207, 212-15 (2011).

25. Id. at 212 .

26. Id.

27. Id.

28. See Peter Van Buren, State of the Campaign Against Whistleblowers, CBS News (Feb. 9, 2012, 2:35 PM), http://www.cbsnews.com/8301-215_162-57374034/state-of-the-campaign-againstwhistleblowers/ (discussing the increased amount of charges brought under the Espionage Act by the Obama administration).

29. Id.

30. See Scott Shane, Ex Contractor is Charged in Leaks on N.S.A. Surveillance, N.Y. TIMES (June 21, 2013), http://www.nytimes.com/2013/06/22/us/snowden-espionageact.html?pagewanted=all\&_r=0. 
face. $^{31}$

Why do so many employers and those with oversight authority react negatively to whistleblowers? One leading plaintiffs' attorney in this area of the law believes that employers' negative responses are due to simple human nature. As Stephen Kohn states, "No one likes to be told that she may have violated a law." 32 In addition, there is evidence that companies' corporate culture instills fear of reporting improper or illegal behavior. $^{33}$ As noted above, a potential explanation for lack of regulatory support for whistleblowers is that agencies bow to political pressure. ${ }^{34}$ Another explanation is simply the lack of resources for the investigation of whistleblower allegations. ${ }^{35}$

While these problems may prevent some whistleblowers from receiving a positive reaction within their company or from a regulatory agency, in theory, a court's adjudication of whistleblower claims should not be affected by these problems. Not being a part of the corporate entity engaged in wrongdoing, a judge should be able to neutrally assess the validity of a whistleblower's complaint. In addition, because of the at least semi-independent nature of the judiciary, judges should be free from the political pressures that affect agencies. While courts have struggled with increasing dockets ${ }^{36}$ and the concomitant limitation on resources, they are not free to simply ignore the whistleblower cases that arise. Thus, it would seem that the court system would be, at worst, neutral for whistleblowers.

31. TOM Devine \& TAReK F. MaAssarani, The Corporate Whistleblower's Survival GuIDE 19-40 (2011) (explaining common methods of "Targeting Dissenters" and "Neutralizing Dissent").

32. Stephen M. Kohn, The Whistleblower's Handbook: A SteP-By-Step Guide to DOING WHAT'S RIGHT AND PROTECTING YOURSELF 19 (2011).

33. See id.

34. See Nielsen, supra note 6, at 388-89. An example of the effect politics has on agency response is evident in the recent shift in the legal standards the Department of Labor applies to Sarbanes-Oxley whistleblower claims. The current Administrative Review Board has overruled Bush-era decisions in these cases. See, e.g., Zinn v. Am. Commercial Lines Inc., ARB No. 10-029, 2012 WL 1143309 (Dep't of Labor Admin. Rev. Bd. Mar. 28, 2012) (establishing new standards applicable to Sarbanes-Oxley whistleblower claims); Sylvester v. Parexel Int'l LLC, ARB No. 07123, 2011 WL 2165854 (Dep't of Labor Admin. Rev. Bd. May 25, 2011).

35. See Nielson, supra note 6, at 386-87 (discussing lack of resources within regulatory agencies devoted to investigating whistleblowing allegations).

36. See, e.g., Judicial Facts and Figures 2011 tbl.6.1, United States Courts (2011), available at http://www.uscourts.gov/Statistics/JudicialFactsAndFigures/judicial-facts-figures2011.aspx (showing 266,783 civil and criminal cases filed in U.S. District Courts in 1990 compared to 367,692 civil and criminal cases filed in 2011). 


\section{B. Understanding Whistleblower Cases}

Whistleblower cases present themselves in a myriad of forms. Cases differ because not only are there federal and state statutes that afford protection to whistleblowers, but there are also common law protections available. ${ }^{37}$ Most of the federal statutes are topic specific: that is, they protect only whistleblowers who disclose an employer's misconduct regarding a particular issue. ${ }^{38}$ SOX, for example, protects employees who disclose securities fraud as well as related wrongdoing. ${ }^{39}$ There are federal statutes protecting employees who disclose violations of federal law relating to transportation, banking, nuclear power plants, health care, and a host of other areas. ${ }^{40}$ These statutes are primarily designed to protect employees in the private sector. ${ }^{41}$ The bulk of these federal statutes require administrative exhaustion before the whistleblower can bring suit in federal court. ${ }^{42}$

Looking beyond federal protection, employees may also be protected by state statutes. Some of these mirror federal statutes and are topic specific. $^{43}$ Others, however, are broadly worded and protect whistleblowers who disclose a wide variety of wrongdoing. For example, Minnesota has a whistleblower protection statute that protects employees who report illegal activity, refuse to engage in illegal activity, or testify regarding illegal activity. ${ }^{44}$ Despite the apparent breadth of statutes such as Minnesota's, the majority of state statutes only protect government employees, not employees in the private sector. ${ }^{45}$

In addition to these statutory protections, nearly every state also

37. See Westman \& ModesitT, supra note 3, at 56-153 (describing various types of protections available to whistleblowers in the public sector, private sector, and under common law).

38. See, e.g., 42 U.S.C. $\$ 5851$ (2012) (providing protection for reporting violations of the Atomic Energy Act). An exception is the Whistleblower Protection Act, which applies to all federal employees. 5 U.S.C. §§ 1211-1219, 1221, 1222, 3352 (2012).

39. Sarbanes-Oxley Act of $2002 \S 806,18$ U.S.C. $\S 1514$ A (2012).

40. See Westman \& ModesitT, supra note 3, app. C (listing various federal statutes that protect whistleblowers).

41. See id.

42. See, e.g., 18 U.S.C. $§ 1514$ A (2012) (requiring a whistleblower to first file a complaint with the Secretary of Labor to issue a final decision within 180 days prior to bringing an action in the appropriate district court); see also WESTMAN \& MODESITT, supra note 3, app. C (listing administrative requirements included in federal whistleblowing statutes).

43. See, e.g., LA. REv. STAT. ANN. §§ 23:967-968 (2012) (protecting employees from retaliation for reporting violations of law).

44. MinN. STAT. § 181.932 (2013).

45. See Westman \& ModesitT, supra note 3, apps. A, B (2004 ed. \& Supp. 2012) (listing state whistleblower protection statutes, most of which concern exclusively public sector employees). 
recognizes a claim for wrongful discharge in violation of public policy. ${ }^{46}$ This common law tort claim provides recourse to employees who are fired for a reason that violates public policy. ${ }^{47}$ The applicability of this claim overlaps in some respects with state statutory whistleblower protections. Typically, the common law claim includes protection for employees who refuse to engage in unlawful activities as well as for employees who report their employer's unlawful conduct. ${ }^{48}$

\section{Court Responses to Whistleblowing Plaintiffs}

There is little data available on the outcomes of whistleblower claims in federal or state courts. What is known about whistleblower claims is nearly entirely anecdotal, but there are a few exceptions. First, Richard Moberly conducted a study in $2007,{ }^{49}$ which he updated in $2012,{ }^{50}$ on the outcomes of whistleblower claims brought under the Sarbanes-Oxley Act. SOX whistleblowing claims must be brought first before the Occupational Safety and Health Administration (OSHA), not in court. ${ }^{51}$ Professor Moberly initially assessed claims brought over a three-year period and found that employees' claims succeeded a mere $3.6 \%$ of the time before the initial administrative investigation within the OSHA and succeeded only $6.5 \%$ of the time before an administrative law judge. ${ }^{52}$ These low rates of success for whistleblowers did not improve over time. In his 2012 update, Professor Moberley found that only $1.8 \%$ of employee claims were successful at the OSHA investigation stage during the first decade of SOX. ${ }^{53}$

Based on his detailed analysis of the written decisions, Professor Moberly identified several reasons for the low rates of plaintiff success. One common reason employees lost was because they failed to file their

46. See id. at ch. 5 (discussing the ways in which the common law protects whistleblowers). The wrongful discharge claim is not limited to whistleblowers; its coverage is broader and protects employees who assert rights such as the right to receive worker's compensation. Id. at 112-13.

47. Id. at 95 .

48. See, e.g., Schriner v. Meginnis Ford Co., 421 N.W.2d 755, 759 (Neb. 1988) ("Consequently, an action for wrongful discharge lies only when an at-will employee acts in good faith and upon reasonable cause in reporting his employer's suspected violation of the criminal code.").

49. See Moberly, Unfulfilled Expectations, supra note 1.

50. See Moberly, Ten Years Later, supra note 1.

51. See 18 U.S.C. $\$ 1514$ A(b) (2012) ("A person who alleges discharge or other discrimination [under this Act] . . may seek relief . . by-filing a complaint with the Secretary of Labor . . ..).

52. Moberly, Unfulfilled Expectations, supra note 1, at 91.

53. Moberly, Ten Years Later, supra note 1, at 29. 
claims in a timely manner. ${ }^{54}$ Another reason for employees' low win rate was based on statutory coverage: a significant number of employers were found not to be covered by the whistleblower protection provisions of SOX. ${ }^{55}$ Additionally, Moberly found that whistleblower claims were often unsuccessful because courts concluded that employees had not engaged in protected behavior as defined by the Act. ${ }^{56}$ Finally, Moberly found that employees were often unable to provide sufficient evidence to prove that whistleblowing was a contributing factor in the alleged retaliation. ${ }^{57}$

Moberly initially indicated that the sobering results of his research might be partially due to the fact that Sarbanes-Oxley was a new statute, and thus subsequent decisions, including those by district court judges, might broaden the coverage of the Act beyond what the OSHA and administrative judges initially provided. ${ }^{58}$ However, in his 2012 article, Moberly suggested that federal courts instead appear to be following the narrow interpretations found in the original administrative decisions. ${ }^{59}$ While Moberly's findings are not favorable for whistleblowers, the apparently dire prospects for SOX plaintiffs may be mitigated by recent changes in the composition of the Administrative Review Board (ARB) ${ }^{60}$ which reviews the decisions of the administrative law judges within the OSHA. Recent decisions by the ARB have reversed earlier $\mathrm{ARB}$ decisions and have broadened coverage under the Sarbanes-Oxley Act. $^{61}$

While Moberly's research is thorough and its results are disturbing, it is nearly impossible to generalize from his SOX research to other whistleblower cases for several reasons. First, the cases Moberly studied

54. Moberly, Unfulfilled Expectations, supra note 1, at 107.

55. Id. at $109-10$.

56. Id. at $113-14$.

57. Id. at $120-24$.

58. See id. at 72 (stating that the strict legal scrutiny applied to employees' claims may be a result of the "push and pull of defining a new statute's legal boundaries"). Moberly's research suggests that the administrative decisions were becoming more, not less, employer-favorable over time. See Moberly, Unfullfilled Expectations, supra note 1, at 91.

59. See Moberly, Ten Years Later, supra note 1, at 33 (discussing the evidence of federal court rulings that have deferred to the administrative judges' narrow reading of the Act).

60. See id. at 42 (noting that the Obama Administration appointed five new members to the ARB's five-member panel in 2010 and 2011).

61. See, e.g., Spinner v. David Landau \& Assocs., ARB No. 10-111, 10-115, 2012 WL 1999677, at *12 (Dep't of Labor Admin. Rev. Bd. May 31, 2012); Zinn v. Am. Commercial Lines Inc., ARB No. 10-029, 2012 WL 1143309, at *4-5 (Dept. of Labor Admin. Rev. Bd. Mar. 28, 2012); Sylvester v. Parexel Int'l LLC, ARB No. 07-123, 2011 WL 2165854, at *19 (Dept. of Labor Admin. Rev. Bd. May 25, 2011). 
were decided within a federal agency, the Department of Labor. It is far from certain that state administrative tribunals would come to similar decisions, much less that state courts would reach similar outcomes. Second, the cases were decided under one specifically-focused federal statute-the Sarbanes-Oxley Act. As Moberly discovered, the OSHA and administrative judges were interpreting this statute, with its focus on exposing fraud within publicly held corporations, very narrowly. ${ }^{62}$ Such narrow interpretations would seem to be less likely where the statute was more generally worded to protect whistleblowers in a wide variety of situations. Thus, extrapolating Moberly's results to state whistleblower suits under either a common law theory of wrongful discharge or a generalized statute protecting whistleblowers is questionable.

The other empirical study that tangentially involved whistleblowers was conducted by David Benjamin Oppenheimer, who studied jury verdicts in employment claims brought in California. ${ }^{63}$ The study compared verdicts in employment discrimination cases with those in wrongful discharge cases. ${ }^{64}$ Oppenheimer concluded that plaintiffs won wrongful discharge claims more frequently than employment discrimination claims, although the difference was not statistically significant. ${ }^{65}$ There were a few interesting details that directly address whistleblowers in this study. First, claims brought by whistleblowers were more likely to result in a plaintiff's verdict than general wrongful discharge claims. Whistleblowers obtained a favorable verdict $63 \%$ of the time, as compared to 59\% for all wrongful discharge claims and 50\% for employment discrimination claims. ${ }^{66}$ Second, it appears that sex and race may have had significant impact on the outcome of some employment claims. According to the study, females who alleged sexual discrimination and non-whites who alleged racial discrimination fared worse than other types of employment claims in front of a jury. ${ }^{67}$ Because Professor Oppenheimer studied jury verdicts, his research did not include information on how whistleblowers fared before reaching the

62. See Moberly, Unfulfilled Expectations, supra note 1, at 90.

63. David Benjamin Oppenheimer, Verdicts Matter: An Empirical Study of California Employment Discrimination and Wrongful Discharge Jury Verdicts Reveals Low Success Rates for Women and Minorities, 37 U.C. DAVIS L. REV. 511 (2003).

64. Id. at 532-35.

65. Id. at 535 (reporting a verdict success rate for plaintiffs of $50 \%$ in statutory employment discrimination cases and $59 \%$ in common law wrongful discharge claims).

66. Id. at 536, 538-39. Again, this difference is not statistically significant. Id. at 538 .

67. Id. at 552 . 
jury. ${ }^{68}$ Thus, it does not furnish information on the rates at which whistleblower claims succeed.

These studies provide limited insight into how whistleblowers fare in the legal system; Mobley's, because it is focused on a very narrow statutory right and on federal administrative decision-makers, and Oppenheimer's because the data on whistleblowers was limited to jury verdicts.

\section{Court Responses to Plaintiffs Bringing Other Claims}

Because of the paucity of empirical studies on whistleblowers, it is helpful to consider how plaintiffs fare in cases outside the whistleblowing context. There are analyses of how employees outside of the whistleblower context fare in litigation that provide data usable for comparative purposes to explore whether whistleblowers succeed more or less often than other employees. ${ }^{69}$ Probably the most similar context that has been studied involves outcomes in employment discrimination cases. These cases present a comparator group of plaintiffs suing their former employers, a similar setting to whistleblower litigation. The central finding of these studies is that employment discrimination plaintiffs do not fare particularly well. ${ }^{70}$ In their seminal articles on the topic, Kevin Clermont and Stewart Schwab determined that plaintiffs in employment discrimination cases fared worse at both the trial level and on appeal than other federal plaintiffs. ${ }^{71}$

While their initial work was a number of years ago, Clermont and Schwab recently updated their research on employment discrimination success rates for plaintiffs in federal court and found the same patterns persisting and, in some instances, becoming even worse. ${ }^{72}$ On appeal, decisions and verdicts in favor of plaintiffs were reversed far more frequently than those in favor of defendants. ${ }^{73}$ Pretrial decisions in favor of plaintiffs were reversed $30 \%$ of the time on appeal, while pretrial

68. See id.

69. See, e.g., Kevin M. Clermont \& Stewart J. Schwab, How Employment Discrimination Plaintiffs Fare in Federal Court, 1 J. EMPIRICAL LEGAL STUD. 429 (2004) [hereinafter Clermont \& Schwab, Employment Discrimination Plaintiffs].

70. Id.

71. Id. at $455-56$.

72. See Kevin M. Clermont \& Stewart J. Schwab, Employment Discrimination Plaintiffs in Federal Court: From Bad to Worse?, 3 HARV. L. \& POL'Y REV. 103 (2009) [hereinafter Clermont \& Schwab, From Bad to Worse].

73. Id. at 110 . 
decisions in favor of defendants were reversed in only $11 \%$ of cases. ${ }^{74}$ When the plaintiff prevailed at trial, decisions were reversed on appeal $41 \%$ of the time, while defendants who prevailed at trial were only reversed $9 \%$ of the time. ${ }^{75}$ The authors found these results particularly disturbing because of the nature of employment discrimination claims, where the outcome is fact-specific and focuses on the intent of the defendant. $^{76}$ Clermont and Schwab concluded that there was an antiplaintiff effect in play. ${ }^{77}$ This effect was also seen at the district court level, where employment discrimination plaintiffs prevailed in only $15 \%$ of cases as contrasted with a win rate of $51 \%$ for plaintiffs in other types of cases. ${ }^{78}$ Similarly, plaintiffs in employment discrimination cases won at trial $28 \%$ of the time, which is far less often than plaintiffs in other federal cases, who enjoyed a win rate of approximately $45 \% .^{79}$ In general, plaintiffs in tort cases brought in state courts prevail at trial approximately $50 \%$ of the time. ${ }^{80}$

Based on the limited available research on whistleblowing and the competing possibilities of outcomes akin to employment discrimination litigation versus tort litigation, it seemed necessary to obtain additional information on how whistleblowing plaintiffs fare in the legal system. Do whistleblower plaintiffs have win rates similar to tort plaintiffs in state courts, employment discrimination plaintiffs in federal courts, or closer to what Moberly found in Sarbanes-Oxley administrative tribunals?

\section{RESEARCHING WHISTLEBLOWER CASES}

This research is limited in scope. It is an initial look at a set of cases from the first quarter of 2012 that are available on a commercial database. This research is based on opinions taken from a commercial database rather than data directly from state court systems for several reasons. First, obtaining the data directly from court filings appeared to

74. Id.

75. $I d$.

76. Id. at 112 .

77. Id. at $104-05$.

78. Id. at 127. These figures are for cases not resulting in a settlement.

79. Id. at 129.

80. See Thomas H. Cohen, U.S. Dep't of Justice, Bureau of Justice Statistics, Tort BENCH AND JURY TRIALS IN STATE COURTS, 2005 12-13 (2009), available at http://www.bjs.gov/index.cfm?ty=pbdetail\&iid=2132 (noting that the win rate at trial for plaintiffs remained stabled between 1996 and 2005). 
be nearly impossible. ${ }^{81}$ State courts do not have a uniform system of coding the type of civil case filed, which presents difficulties in ensuring accurate comparisons between cases brought in different states. ${ }^{82}$ In addition, whistleblower cases do not appear to be a category that is even listed on some state cover sheets. ${ }^{83}$ Thus, obtaining data directly from state courts' systems on whistleblowers would require a researcher to locate whistleblowing complaints in some states by reviewing all tort filings - a prohibitively expensive and time-consuming process.

While it is my sense from having read hundreds of whistleblowing cases in my career that the results of this research are generally representative, it is not possible to determine whether the sample used in this research is in fact representative of all state whistleblower cases.

\section{A. Research Methodology}

The cases in this study were obtained by conducting specific, datelimited, terms-and-connectors searches in a commercial database. Results were reviewed, coded according to the type of retaliatory conduct claim, and sorted into one of the following groups: (1) no employment retaliation claim at all; ${ }^{84}$ (2) a retaliation claim brought pursuant to a non-whistleblower statute (such as Title VII of the Civil Rights Act of 1964); or (3) a whistleblower claim brought pursuant to a whistleblower protection statute or a whistleblower-retaliation claim brought under the common law doctrine of wrongful discharge in violation of public policy. Decisions from the third category were then analyzed; decisions from the first two categories were not. ${ }^{85}$

81. For example, Virginia does not have any category on its civil case cover sheet that identifies an employment claim or a wrongful discharge claim. See Commonwealth of Virginia, Cover SHEET FOR FILING CIVIL ACTIONS, www.courts.state.va.us/forms/circuit/cc1416.pdf (last visited Sept. 1, 2013) [hereinafter VIRGINIA Civil COVER SHEET]. California, in contrast, identifies Employment as a broad category and wrongful termination as a subcategory. See CALIFORNIA COURTS, CIVIL CASE COVER SHEET, www.courts.ca.gov/documents/cm010.pdf (last visited Sept. 1, 2013).

82. This may be why many studies of outcomes in litigation use federal court cases- the consistency of the federal cover sheet ensures consistent data across the country.

83. See, e.g., VIRGINIA CIVIL COVER SHEET, supra note 81.

84. Because the searches were word searches that required certain terms to be present in the cases, it resulted in obtaining cases that used the terms but failed to involve an actual retaliation claim made by an employee.

85. Decisions from the first category were irrelevant - these decisions happened to mention terms in the search criteria but did not involve retaliation by an employer against an employee who complained of wrongdoing. Decisions from the second category are relevant, but the majority of them primarily involved employment discrimination claims with a retaliation claim appended. My 
This third group of cases was further narrowed to include only cases where the court addressed the substance of a whistleblowing claim. A number of cases involved discovery rulings or other non-substantive issues such as whether an arbitration agreement should be enforced. These cases were not analyzed because this research seeks an initial sense of how courts react to the substance of whistleblowing claims. Courts may rule on discovery issues substantively differently in whistleblowing cases than in non-whistleblowing cases, but that is not the focus of this research. For cases involving multiple claims, only cases where a whistleblowing claim was substantively addressed in the opinion were included in the data pool. ${ }^{86}$ Thus, it is possible that in such cases a lower court did address the substance of the whistleblowing claim, but these earlier decisions were not a part of the data pool and were not considered. Similarly, some whistleblowing claims from the data may have subsequently been addressed on appeal; once again, these were not included.

Once narrowed down to opinions in which the court addressed the substance of the whistleblower claim, the cases were then coded according to outcome. The outcomes included the plaintiff's win-loss ratio as well as the manner of resolution (i.e. motion to dismiss granted, summary judgment denied, or jury verdict upheld).

\section{B. Results}

There were a total of 34 cases in which the court opinion addressed the substance of the whistleblower allegations. ${ }^{87}$ The opinions were

concern with these cases is that state courts tend to incorporate Title VII retaliation doctrines, and including these cases would mask outcomes and doctrines used in whistleblowing cases outside of the Title VII context.

86. There were several cases that were wrongful discharge claims that did not involve whistleblowers. These cases were not included in the final pool of cases.

87. Coombs v. J.B. Hunt Transp, Inc., 388 S.W.3d 456 (Ark. Ct. App. 2012); Brown v. Cnty. of L.A., 138 Cal. Rptr. 3d 380 (Cal. Ct. App. 2012); Paras v. Delta Dental of Cal., A131055, 2012 WL 629997 (Cal. Ct. App. Feb. 27, 2012); Luu v. Luu's Bros. Corp., No. C065408, 2012 WL 406908 (Cal. Ct. App. Feb. 8, 2012); Brown v. State Personnel Bd., No. F059897, 2012 WL 274349 (Cal. Ct. App. Jan. 27, 2012); Morales v. Waste Mgmt. of Alameda Cnty., Inc., No. A131130, 2012 WL 243231 (Cal. Ct. App. Jan. 26, 2012); Swindle v. Res-Care Cal., Inc., No. C062562, 2012 WL 86406 (Cal. Ct. App. Jan. 11, 2012); Mize-Kurzman v. Marin Cmty. Coll. Dist., 136 Cal. Rptr. 3d 259 (Cal. Ct. App. 2012); Li Li v. Canberra Indus., 39 A.3d 789 (Conn. App. Ct. 2012); Cubilla v. Town of Montville, No. KNLCV116010874S, 2012 WL 800909 (Conn. Super. Ct. Feb. 17, 2012); Carlson v. Sheriden Woods Health Care Ctr., No. HHDCV116025384S, 2012 WL 753756 (Conn. Super. Ct. Feb. 14, 2012); Conn. Dep't of Mental Health and Addiction Servs. v. Saeedi, No. CV116008678S, 2012 WL 695512 (Conn. Super. Ct. Feb. 7, 2012); Kulmann v. Yale-New Haven Hosp., No. NNHCV106010414, 2012 WL 234218 (Conn. Super. Ct. Jan. 4, 2012); Bollinger v. Fall River Rural 
heavily weighted toward appellate decisions, as one would expect when using a commercial database. Out of the 34 cases, 28 were decisions issued by a court of appeals. Only 2 of these 28 appellate decisions were issued by a state's highest court. The remaining 6 opinions were issued by a trial court.

\section{Rates of Success and Failure}

While the vast majority of the opinions in the study were appellate decisions, these decisions necessarily included the outcomes at the trial level, making it possible to broadly analyze whistleblower success rates. $^{88}$ Employers prevailed on the pending legal issue at the trial level in 26 out of 34 opinions, for a success rate of $76 \%{ }^{89}$ Only the appellate decisions included the final disposition of the whistleblower cases at the trial level. Out of the 28 appellate decisions, the employer prevailed at the trial court level in the vast majority of cases, as indicated in 26 out of

Elec. Coop., Inc., 272 P.3d 1263 (Idaho 2012); Ulm v. Mem'l Med. Ctr., 964 N.E.2d 632 (Ill. App. Ct. 2012); Dysert v. Review Bd. of Dept. of Workforce Dev., No. 93A02-1105-EX-392, 2012 WL 10142 (Ind. Ct. App. Jan. 3, 2012); East v. Office of Inspector Gen., 87 So.3d 925 (La. Ct. App. 2012); Todd v. Kilpatrick, No. 300594, 2012 WL 470062 (Mich. Ct. App. 2012); Stay v. Connections Emp't Res., No. 301709, 2012 WL 407500 (Mich. Ct. App. Feb. 9, 2012); Wielen v. City of Bay City, No. 298256, 2012 WL 407266 (Mich. Ct. App. Feb. 9, 2012); Vanderlaan v. Mich. Med., P.C., No. 300660, 2012 WL 284580 (Mich. Ct. App. Jan. 31, 2012); Prieskorn v. Univ. of Mich. Health Sys., No. 298996, 2012 WL 205801 (Mich. Ct. App. Jan. 24, 2012); King v. Chrysler Grp. LLC, No. 301246, 2012 WL 164202 (Mich. Ct. App. Jan. 19, 2012); Dooms v. First Home Sav. Bank, 376 S.W.3d 666 (Mo. Ct. App. 2012); Teetor v. Dawson Pub. Power Disc., 808 N.W.2d 86 (Neb. Ct. App. 2012); Ainsworth v. Newmont Mining Corp., No. 56250, 2012 WL 987222 (Nev. March 20, 2012); Medina v. Dep't of Educ. of N.Y., No. 101823/2011, 2012 WL 987601 (N.Y. Sup. Ct. Feb. 15, 2012); Connolly v. Napoli, Kaiser \& Bern, LLP, No. 105334/05, 2012 WL 205961 (N.Y. Sup. Ct. Jan. 13, 2012); Pierce v. Atl. Grp., Inc., 724 S.E.2d 568 (N.C. Ct. App. 2012); Williams v. City of Burns, No. M2010-02428-COA-R3-CV, 2012 WL 504511 (Tenn. Ct. App. Feb. 15, 2012); Quinn-Glover v. Reg'l Med. Ctr., No. W2011-00100-COA-R3-CV, 2012 WL 120209 (Tenn. Ct. App. Jan. 17, 2012); Nairn v. Killeen Indep. Sch. Dist., 366 S.W.3d 229 (Tex. App. 2012); S. Tex. Coll. v. Roberson, No. 13-10-00561-CV, 2012 WL 506324 (Tex. App. Feb. 16, 2012); Mullins v. Dall. Indep. Sch. Dist., 357 S.W.3d 182 (Tex. App. 2012).

88. The limitations of using cases contained in a commercial database become evident here. Westlaw does not obtain all trial court decisions on motions to dismiss and on summary judgment; in fact, it seems likely that a relatively small proportion of them are reported.

89. Coombs, 388 S.W.3d at 459; Paras, 2012 WL 629997, at *1; Luu, 2012 WL 406908, at *1; Brown, 2012 WL 274349, at*1; Morales, 2012 WL 243231, at*1; Swindle, 2012 WL 86406, at *3; Mize-Kurzman, $136 \mathrm{Cal}$. Rptr. 3d at 265-66; Li Li, 39 A.3d at 791; Bollinger, 272 P.3d at 1266; Ulm, 964 N.E.2d at 636; Dysert, 2012 WL 10142, at 3; East, 87 So.3d at 925; Todd, 2012 WL 470062, at *1; Stay, 2012 WL 407500, at *2; Wielen, 2012 WL 407266, at *1; Vanderlaan, 2012 WL 284580, at *1; Prieskorn, 2012 WL 205801, at *1; King, 2012 WL 164202, at*1; Teetor, 808 N.W.2d at 89; Ainsworth, 2012 WL 987222, at *1; Pierce, 724 S.E.2d at 571; Williams, $2012 \mathrm{WL}$ 504511, at *1; Quinn-Glover, 2012 WL 120209, at*1; Nairn, 366 S.W.3d at 236; Roberson, 2012 WL 506324, at *1; Mullins, 357 S.W.3d at 185. 
the 28 opinions, for a success rate of $93 \%$. This percentage may be overstating employer success rates at the trial level. Out of the 28 appellate opinions, only 2 involved plaintiffs who prevailed at the trial level; both were jury trials. ${ }^{90}$ The only other way that a plaintiff prevails at the trial level in whistleblower cases is for the plaintiff to settle the case. These cases are not captured by this study. In 17 of the 34 cases (50\%), the trial court found in favor of the employer on a motion for summary judgment (or equivalent) on the whistleblowing claim. ${ }^{91}$ Four out of the 34 cases $(12 \%)$ went to a trial or administrative hearing - the functional equivalent to a trial-in which the employer prevailed. ${ }^{92}$ The employer prevailed on a motion to dismiss (or demurrer) at the trial level in the remaining 5 employer-favorable decisions out of the 34 cases $(15 \%){ }^{93}$

Employers also enjoyed significant success at the appellate level. The overall affirmation rate of trial court decisions in favor of the employer was $81 \%$ ( 21 out of 26 cases). ${ }^{94}$ The rates were similar regardless of the type of trial court decision. Of the 17 summary judgment decisions, the appellate court affirmed the trial court's grant of summary judgment to the employer in 14 cases. ${ }^{95}$ Thus, on summary

90. Brown, 138 Cal. Rptr. 3d at 381; Dooms, 376 S.W.3d at 669. Additionally, another plaintiff prevailed at an administrative hearing, which was confirmed in a subsequent district court decision as included in whistleblower success rates below. Saeedi, 2012 WL 695512, at *13.

91. Coombs, 388 S.W.3d at 459; Paras, 2012 WL 629997, at*1; Morales, 2012 WL 243231, at *1; Swindle, 2012 WL 86406, at *3; Li Li, 39 A.3d at 791; Bollinger, 272 P.3d at 1266; Ulm, 964 N.E.2d at 636; Todd, 2012 WL 470062, at *1; Stay, 2012 WL 407500, at *2; Wielen, 2012 WL 407266, at *1; Vanderlaan, 2012 WL 284580, at *1; Prieskorn, 2012 WL 205801, at *1; King, 2012 WL 164202, at *1; Teetor, 808 N.W.2d at 89; Ainsworth, 2012 WL 987222, at *1; Williams, 2012 WL 504511, at *1; Nairn, 366 S.W.3d at 236.

92. Brown, 2012 WL 274349, at *1; Mize-Kurzman, 136 Cal. Rptr. 3d at 265-66; Dysert, 2012 WL 10142, at *3; East, 87 So.3d at 925.

93. Luu, 2012 WL 406908, at*1; Pierce, 724 S.E.2d at 571; Quinn-Glover, 2012 WL 120209, at $* 1$; Roberson, 2012 WL 506324, at *1; Mullins, 357 S.W.3d at 185. Both Roberson and Mullins involved special pleas of immunity instead of traditional motions to dismiss.

94. Coombs, 388 S.W.3d at 464; Paras, 2012 WL 629997, at *1; Brown, 2012 WL 274349, at *6; Morales, 2012 WL 243231, at*6; Swindle, 2012 WL 86406, at*9; Bollinger, 272 P.3d at 1274; Ulm, 964 N.E.2d at 645; Dysert, 2012 WL 10142, at *5; East, 87 So.3d at 929; Stay, 2012 WL 407500, at*5; Wielen, 2012 WL 407266, at*5; Vanderlaan, 2012 WL 284580, at *4; Prieskorn, 2012 WL 205801, at *4; King, 2012 WL 164202, at *5; Teetor, 808 N.W.2d at 95; Ainsworth, 2012 WL 987222, at *4; Pierce, 724 S.E.2d at 579; Quinn-Glover, 2012 WL 120209, at *7; Nairn, 366 S.W.3d at 251; Roberson, 2012 WL 506324, at *3; Mullins, 357 S.W.3d at 192.

95. Coombs, 388 S.W.3d at 464; Paras, 2012 WL 629997, at*1; Morales, 2012 WL 243231, at *6; Swindle, 2012 WL 86406, at *9; Bollinger, 272 P.3d at 1274; Ulm, 964 N.E.2d at 645; Stay, $2012 \mathrm{WL} 407500$, at $* 5$; Wielen, $2012 \mathrm{WL} 407266$, at $* 5$; Vanderlaan, 2012 WL 284580, at *4; Prieskorn, 2012 WL 205801, at *4; King, 2012 WL 164202, at *5; Teetor, 808 N.W.2d at 95; Ainsworth, 2012 WL 987222, at *4; Nairn, 366 S.W.3d at 251. 
judgment motions, trial courts were affirmed in favor of employers $82 \%$ of the time and reversed $18 \%$ of the time. The rates were similar for cases decided on motions to dismiss. Four out of the 5 cases in which the employer prevailed on a motion to dismiss were affirmed by the appellate court ${ }^{96}$ (although in 2 of these cases the appellate court upheld the dismissal of the whistleblower claim but remanded the cases to allow the plaintiff to amend the complaint ${ }^{97}$ ). Appellate courts upheld 3 out of the 4 decisions in which the employer prevailed at a trial or administrative hearing. ${ }^{98}$

TRIAL LEVEL SUCCESS RATES ${ }^{99}$

\begin{tabular}{|l|l|l|l|}
\hline & Motion to Dismiss & Summary Judgment & Trial \\
\hline $\begin{array}{l}\text { Employer } \\
\text { Prevailed }\end{array}$ & $15 \%$ & $50 \%$ & $12 \%$ \\
\hline $\begin{array}{l}\text { Employee } \\
\text { Prevailed }\end{array}$ & N/A & N/A & $9 \%$ \\
\hline
\end{tabular}

On the other side, employees succeeded on the merits of their whistleblowing claims at the trial court level or administrative hearing

96. Pierce, 724 S.E.2d at 579; Quinn-Glover, 2012 WL 120209, at *7; Roberson, $2012 \mathrm{WL}$ 506324, at*3; Mullins, 357 S.W.3d at 192.

97. Quinn-Glover, 2012 WL 120209, at*11; Roberson, 2012 WL 506324, at*4.

98. Brown, 2012 WL 274349, at *6; Dysert, 2012 WL 10142, at *5; East, 87 So.3d at 929.

99. It should be noted that the sample size for many of these categories is simply too small to produce statistically significant outcomes. This chart indicates where a party prevailed on the merits of the whistleblowing claim. The total percentages do not add up to 100 because of defendants' losses on motions to dismiss and summary judgment. For these two groups of cases, it is not known whether the defendant or plaintiff ultimately prevailed on the whistleblowing claim —only that the defendant did not win on that particular motion.

100. Obviously there were no cases where a plaintiff won the case on a motion to dismiss. And in this data pool, there were no cases where a plaintiff sought summary judgment on the whistleblowing claim. Thus, the only manner in which plaintiffs prevailed was at trial. 
level in only 3 out of 34 cases, for an initial success rate of $9 \% .{ }^{101}$ Out of the entire population of 34 cases, the employee prevailed on the pending legal matter (motion to dismiss, summary judgment, verdict, or administrative evidentiary finding) at the trial court level 8 times $(24 \%){ }^{102}$ In 4 of the 34 cases $(12 \%)$ the employers' motions to dismiss ${ }^{103}$ were denied by the trial court. ${ }^{104}$ There was 1 denial of a motion for summary judgment included in the study. ${ }^{105}$ Thus, it is unknown whether the plaintiff ultimately prevailed on the whistleblowing claim in these 5 cases.

It is to be expected that the only situation where the plaintiff prevailed on the merits of the whistleblower claim was after a trial or its equivalent. As is typical for a plaintiff in most litigation, the plaintiff bears the burden of proof in these cases, making decisions in favor of the plaintiff at any preliminary stage of the case exceedingly unlikely. Furthermore, it bears mentioning that it is possible that the total win rate for plaintiffs is underrepresented in this study. Plaintiffs prevail before trial by settling on favorable terms, and the database used in this study only included reported decisions; it did not include settlements.

\section{Comparative Analysis to Other Plaintiffs}

It appears whistleblowers fare less favorably than tort plaintiffs generally, as well as employment discrimination plaintiffs specifically. This research indicates that plaintiffs in whistleblower cases prevail at a rate of $9 \%$ at the trial or administrative hearing level. This is slightly less than the $15 \%$ found by Clermont and Schwab for plaintiffs in

101. Brown v. Cnty. of L.A., 138 Cal. Rptr. 3d 380, 385 (Cal. Ct. App. 2012); Conn. Dep't of Mental Health and Addiction Servs. v. Saeedi, No. CV116008678S, 2012 WL 695512, at *13 (Conn. Super. Ct. Feb. 7, 2012); Dooms v. First Home Sav. Bank, 376 S.W.3d 666, 669 (Mo. Ct. App. 2012).

102. Brown, 138 Cal. Rptr. 3d at 385; Cubilla v. Town of Montville, No. KNLCV116010874S, 2012 WL 800909, at*5 (Conn. Super. Ct. Feb. 17, 2012); Carlson v. Sheriden Woods Health Care Ctr., No. HDCV116025384S, 2012 WL 753756, at*1 (Conn. Super. Ct. Feb. 14, 2012); Saeedi, 2012 WL 695512, at *13; Kulmann v. Yale-New Haven Hosp., No. NNHCV106010414, 2012 WL 234218, at *5 (Conn. Super. Ct. Jan. 4, 2012); Dooms, 376 S.W.3d at 669; Medina v. Dep't of Educ. of N.Y., No. 101823/2011, 2012 WL 987601, at *3 (N.Y. Sup. Ct. Feb. 15, 2012); Connolly v. Napoli, Kaiser \& Bern, LLP, No. 105334/05, 2012 WL 205961, at *7 (N.Y. Sup. Ct. Jan. 13, 2012).

103. One of the four was styled a motion to strike, but the substance was essentially that of a motion to dismiss. Cubilla, 2012 WL 800909, at*5.

104. Id.; Carlson, 2012 WL 753756, at *1; Kulmann, 2012 WL 234218, at *5; Medina, $2012 \mathrm{WL}$ 987601 , at $* 3$.

105. Connolly, 2012 WL 205961, at *7. 
employment discrimination cases. ${ }^{106}$ It also compares unfavorably to the overall win rate of plaintiffs in litigation in general, where plaintiffs in federal court prevail approximately $45 \%$ of the time, ${ }^{107}$ and plaintiffs in state court prevail about $50 \%$ of the time. ${ }^{108}$ The plaintiffs in this research at least prevailed slightly more often than the SOX whistleblowers in Moberly's study, who prevailed at the administrative level only $3.6 \%$ of the time, but at a rate of $6.5 \%$ before an administrative law judge. ${ }^{109}$ Out of the 7 total cases in this research that went to trial or an administrative hearing, plaintiffs prevailed in 3, for a success rate of $43 \% .^{110}$ This compares unfavorably to Professor Oppenheimer's study in which whistleblowing plaintiffs prevailed at trial in $63 \%$ of cases. ${ }^{111}$

In terms of appellate review, appellate courts reversed decisions made in favor of the employer in 5 out of 26 appellate cases for a rate of $19 \% .^{112}$ This is a slightly higher rate than Clermont and Schwab discovered for employers in discrimination cases, where defendantfavorable outcomes at the trial and pretrial stage were reversed on appeal only $10 \%$ of the time. ${ }^{113}$ Because Moberly did not address appellate review, there is no comparable data from his SOX research. ${ }^{114}$

\section{Why Courts Deny Whistleblowers Relief}

As noted above, this research is not intended to be a perfectly representative sample of whistleblower cases. Instead, it is an attempt to

\footnotetext{
106. Clermont \& Schwab, From Bad to Worse, supra note 72, at 127.

107. Clermont \& Schwab, Employment Discrimination Plaintiffs, supra note 69, at 442.

108. COHEN, supra note 80, at 13.

109. Moberly, Unfulfilled Expectations, supra note 1, at 67.

110. Brown v. Cnty. of L.A., 138 Cal. Rptr. 3d 380, 385 (Cal. Ct. App. 2012); Conn. Dep't of Mental Health and Addiction Servs. v. Saeedi, No. CV116008678S, 2012 WL 695512, at *13 (Conn. Super. Ct. Feb. 7, 2012); Dooms v. First Home Sav. Bank, 376 S.W.3d 666, 669 (Mo. Ct. App. 2012).

111. Oppenheimer, supra note 63 , at 538 .

112. Luu v. Luu's Bros. Corp., No. C065408, 2012 WL 406908, at*3 (Cal. Ct. App. Feb. 8, 2012); Mize-Kurzman v. Marin Cmty. Coll. Dist., 136 Cal. Rptr. 3d 259, 266 (Cal. Ct. App. 2012); Li Li v. Canberra Indus., 39 A.3d 789, 796 (Conn. App. Ct. 2012); Todd v. Kilpatrick, No. 300594, 2012 WL 470062, at*7 (Mich. Ct. App. 2012); Williams v. City of Burns, No. M2010-02428-COAR3-CV, 2012 WL 504511, at *7 (Tenn. Ct. App. Feb. 15, 2012).

113. Clermont \& Schwab, From Bad to Worse, supra note 72, at 110 . The table on page 110 shows that 1,133 out of 10,598 decisions in favor of employee at the pretrial stage were reversed on appeal and 178 out of 2,042 decisions favorable to employees were reversed on appeal. Id. Cumulatively, this means that 1,311 out of 12,640 trial court employer-favorable decisions were reversed on appeal coming to a percentage of around $10 \%$.
}

114. Moberly, Unfulfilled Expectations, supra note 1, at 86-87. 
gain a first sense of both the success rates for whistleblower cases brought in state courts as well as the reasons for these rates of success. The reasons for success or failure provide some depth and context to the numerical analysis above.

Nearly all decisions reviewed in this research followed the approach used in employment discrimination cases as to the quantum and type of evidence a plaintiff must produce to proceed to trial. ${ }^{115}$ The prima facie case, which is the predominant method of proving retaliation for engaging in whistleblowing, is typically articulated as follows. The plaintiff must establish that: (1) she engaged in protected behavior, such as reporting unlawful activity; (2) she was discriminated against; and (3) there is a causal connection between the protected activity and the discrimination. $^{116}$ Of these three requirements, the causal connection was the one that produced the most difficulty for whistleblowing plaintiffs, as discussed in detail below. ${ }^{117}$

According to this research, even if the plaintiff produces sufficient evidence of causation to establish the prima facie case, causation must again be revisited, and once again it causes evidentiary problems for the plaintiff. If the plaintiff establishes the prima facie case, the burden of proof shifts, just as in employment discrimination cases, to the defendant to articulate a legitimate reason for taking action against the plaintiff. ${ }^{118}$ Once the employer has articulated its legitimate reason for taking the action, the plaintiff can still prevail if she can establish that the stated reason is a pretext. ${ }^{119}$ This implicates causation because the case then revolves around whether the employee was fired because of

115. A few do not follow this approach. See, e.g., Williams v. City of Burns, No. M2010-0248COA-R3-CV, 2012 WL 504511, at *2 n.2 (Tenn. Ct. App. Feb. 15, 2012) (noting that Tennessee has expressly rejected the McDonnell Douglas framework). See also McDonnell Douglas Corp. v. Green, 411 U.S. 792 (1973).

116. See, e.g., Paras v. Delta Dental of Cal., No. A131055, 2012 WL 629997, at *6 (Cal. Ct. App. Feb. 27, 2012) (noting that California follows the McDonnell Douglas framework); Prieskorn v. Univ. of Mich. Health Sys., No. 298996, 2012 WL 205801, at *1 (Mich. Ct. App. Jan. 24, 2012) (following an equivalent Michigan standard).

117. This differs from Moberly's research, where coverage was a significant problem. Moberly, Unfulfilled Expectations, supra note 1, at 109-13. One would expect more plaintiff-favorable outcomes than in Sarbanes-Oxley whistleblower claims because employer-retaliation coverage was not a significant issue in the whistleblowing cases in this research. However, the win rates were fairly comparable at the trial level in my study (9\%) and administrative law judge level $(6.5 \%)$ in Moberly's study. Id. at 91 . This suggests that there is something else driving the outcomes in whistleblower cases and raises the possibility that regardless of rationale used by the court, whistleblowers win rates will remain low.

118. See, e.g., Paras, 2012 WL 629997, at *6.

119. Id. 
whistleblowing or for some other, non-protected reason. The burden of proving causation, whether as a part of the prima facie case or by establishing pretext, was a significant problem for plaintiffs in the sample of cases.

Out of the 34 total whistleblower cases, 15 involved analysis on the cause of the adverse action taken, making it the predominant legal basis for deciding whistleblowing cases in the sample. ${ }^{120}$ Some of these cases analyzed the causation issue as part of the prima facie case; others addressed causation on the issue of pretext. Out of these 15 cases, the trial court found against the plaintiff on the issue of causation 13 times $(87 \%) .{ }^{121}$ All of these 13 cases in which the trial court found that the causal connection could not be established were summary judgment decisions. Thus, these were situations where the trial court determined as a matter of law, looking at the evidence in the light most favorable to the plaintiff, the plaintiff could not establish that the whistleblowing behavior was the cause of the adverse employment action.

Inability to prove causation is the single largest reason that whistleblowers lost their case. ${ }^{122}$ This raises the question: Why do employees lose on causation? Is it due to legal standards, poor job performance, or a lack of evidence linking their protected activity to the adverse employment action? To answer this question, I decided to look beyond the numbers to assess the content of the court decisions in the study. Specifically, I reviewed the text of the decisions as well as any

120. Paras, 2012 WL 629997, at*7; Morales v. Waste Mgmt. of Alameda Cnty., Inc., No. A131130, 2012 WL 243231, at *5 (Cal. Ct. App. Jan. 26, 2012); Swindle v. Res-Care Cal., Inc., No. C062562, 2012 WL 86406, at *4-8 (Cal. Ct. App. Jan. 11, 2012); Li Li v. Canberra Indus., 39 A.3d 789, 795 (Conn. App. Ct. 2012); Conn. Dep't of Mental Health and Addiction Servs. v. Saeedi, No. CV116008678S, 2012 WL 695512, at*13 (Conn. Super. Ct. Feb. 7, 2012); Bollinger v. Fall River Rural Elec. Coop., Inc., 272 P.3d 1263, 1271-72 (Idaho 2012); Todd v. Kilpatrick, No. 300594, 2012 WL 470062, at *6-7 (Mich. Ct. App. 2012); Stay v. Connections Emp't Res., No. 301709, 2012 WL 407500, at*3 (Mich. Ct. App. Feb. 9, 2012); Wielen v. City of Bay City, No. 298256, 2012 WL 407266, at *5 (Mich. Ct. App. Feb. 9, 2012); Vanderlaan v. Mich. Med., P.C., No. 300660, 2012 WL 284580, at *3 (Mich. Ct. App. Jan. 31, 2012); Prieskorn, 2012 WL 205801, at *3-4; King v. Chrysler Grp. LLC, No. 301246, 2012 WL 164202, at*4-5 (Mich. Ct. App. Jan. 19, 2012); Teetor v. Dawson Pub. Power Disc., 808 N.W.2d 86, 92-93 (Neb. Ct. App. 2012); Connolly v. Napoli, Kaiser \& Bern, LLP, No. 105334/05, 2012 WL 205961, at *5-6 (N.Y. Sup. Ct. Jan. 13, 2012); Williams, 2012 WL 504511, at *4-7.

121. Paras, 2012 WL 629997, at*7; Morales, 2012 WL 243231, at*3; Swindle v. Res-Care Cal., Inc., No. C062562, 2012 WL 86406, at *3; Li Li, 39 A.3d at 792; Bollinger, 272 P.3d at 1268; Todd, 2012 WL 470062, at *2; Stay, 2012 WL 407500, at*2; Wielen, 2012 WL 407266, at *1; Vanderlaan, 2012 WL 284580, at *1; Prieskorn, 2012 WL 205801, at*1; King, 2012 WL 164202, at *1; Teetor, 808 N.W.2d at 89; Williams, 2012 WL 504511, at*1.

122. This issue was similarly a problem that Moberly discovered in his analysis of plaintiffs in Sarbanes-Oxley cases. See Moberly, Unfulfilled Expectations, supra note 1, at 124-28. 
available briefs filed by the parties on appeal. ${ }^{123}$

The cases from the sample provide insight and help explain the infrequency of plaintiff success. As discussed above, courts decided the bulk of summary judgment motions against the plaintiffs based on the court's belief that causation cannot be established as a matter of law. Causation considers whether the employee was subject to adverse action because she engaged in protected activity or for another, legitimate reason. In situations where employees produced sufficient evidence of pretext to withstand summary judgment, there appeared to be two factors at play: (1) the court's articulation of the evidence necessary to establish pretext; and (2) the court's willingness to ignore or dismiss out of hand the employee's evidence that tends to disprove or cast doubt on the employer's stated rationale for the adverse action taken against the employee. $^{124}$

In the 13 cases where causation was decided against the plaintiff (either in the prima facie case or in the analysis of pretext) at the trial court level, $6(46 \%)$ appear to involve trial courts making factual determinations that should reside with the jury. ${ }^{125}$ In 3 out of the 13 cases $(23 \%)$, the appellate court reversed the trial court's grant of summary judgment. ${ }^{126}$ This reversal rate was actually slightly higher than the overall reversal rate for employers, which was $19 \%$.

\section{Imposing a Causation Standard that is Unfavorable to Employees}

Courts improperly granting summary judgment on causation create an unfavorable standard employees struggle to overcome. Vanderlaan $v$. Michigan Medical P.C. exemplifies both issues: legal standards on causation that limit the ability of plaintiffs to succeed as well as considering the facts in a light that is not favorable to the employee. ${ }^{127}$

123. For the trial court decisions, briefs were not available.

124. This is in contravention of the legal standard for granting summary judgment, which requires considering the facts in the light most favorable to the non-moving party (the employeeplaintiff). See, e.g., Vanderlaan, $2012 \mathrm{WL} 284580$, at $* 2$ ("The trial court is not permitted to assess credibility, or to determine facts on a motion for summary disposition." (citation omitted)).

125. Many of these cases will be discussed below. Swindle v. Res-Care Cal., Inc., No. C062562, 2012 WL 86406 (Cal. App. Jan. 11, 2012); Wielen v. City of Bay City, No. 298256, 2012 WL 407266 (Mich. App. Feb. 9, 2012); Vanderlaan, 2012 WL 284580; Prieskorn v. Univ. of Mich. Health Sys., No. 298996, 2012 WL 205801 (Mich. App. Jan. 24, 2012); King v. Chrysler Grp. LLC, No. 301246, 2012 WL 164202 (Mich. App. Jan. 19, 2012); Teetor v. Dawson Pub. Power Dist., 808 N.W.2d 86 (Neb. Ct. App. 2012).

126. Li Li, 39 A.3d at 796; Todd, 2012 WL 470062, at *7; Williams, 2012 WL 504511, at*1.

127. No. 300660, 2012 WL 284580 (Mich. Ct. App. Jan. 31, 2012). 
In Vanderlaan, the plaintiff articulated concerns that his employer was not complying with federal law regarding billing practices in a medical clinic and he was terminated a short time later. ${ }^{128}$ The trial court granted summary judgment, apparently based on a lack of evidence of a causal connection between the plaintiff's protected activity and his termination. $^{129}$ On appeal, the Michigan Court of Appeals upheld the trial court's decision, stating that, "Plaintiff has presented no evidence, other than temporal proximity, connecting his protected activity to his termination. A short time period between plaintiff engaging in protected activity and the termination of plaintiff's employment, without more, is insufficient to establish a causal connection between the termination and the protected activity." $" 130$

Vanderlaan is not alone in its employer-favorable standards on causation. Even temporal proximity coupled with a strong motive to fire an employee who is making a protected report has been held to be insufficient as a matter of law to establish the causal link when the employer provided evidence of employee misbehavior on the job. ${ }^{131}$ Along similar lines, temporal proximity coupled with evidence that the employee had received positive employment evaluations before making a report has been considered insufficient to establish that the employer's stated reason for taking action is pretextual. ${ }^{132}$

Close temporal proximity between protected conduct and adverse employment action should be sufficient to establish causation for the purposes of establishing a prima facie case. Furthermore, there is support for this proposition in whistleblowing cases brought under federal law. For example, this standard of temporal proximity fulfilling the prima facie case has been accepted for whistleblowing claims

\footnotetext{
128. Id. at *1.

129. Id. at *3

130. Id.

131. See King v. Chrysler Grp. LLC, No. 301246, 2012 WL 164202, at*3 (Mich. Ct. App. Jan. 19, 2012) (accepting the employer's articulated reason for firing the plaintiff in upholding summary judgment for the employer); Plaintiff-Appellant's Reply Brief, King, 2012 WL 164202 (No. 301246), $2011 \mathrm{WL} 7627351$ (arguing evidence of pretext through both temporal proximity and the employee's report of wastewater overflow under a new policy that prohibited employees from reporting such overflows to the government to protect the company from heightened scrutiny and possible fines). The appellate court accepted the causation argument, but ruled for the defendant because King failed to establish how his firing was pretextual. King, 2012 WL 164202, at*5.

132. See, e.g., Teetor v. Dawson Pub. Power Dist., 808 N.W.2d 86, $92-93$ (Neb. Ct. App. 2012). In Teetor, the court determined that the plaintiff failed to provide sufficient evidence of pretext despite complaining about allegedly improper conduct. Id. The court focused on formal grievance as the report of such conduct rather than the date on which the plaintiff initially protested the
} improper conduct. Id. 
brought under the Sarbanes-Oxley Act. ${ }^{133}$

Once the plaintiff establishes the prima facie case and introduces evidence that casts doubt on the employer's explanation for its decision, whistleblower claims should be handled no less favorably than employment discrimination claims. ${ }^{134}$ In both instances, the prima facie case plus disproving evidence should be sufficient to allow the case to reach the jury.

A recent decision involving wrongful discharge that was not a whistleblower claim illustrates this approach. Shipp v. Mason General Hospital Foundation, out of the Washington Court of Appeals, was decided during the same time period as the cases in this study. ${ }^{135}$ It was not included in the pool of cases analyzed because the wrongful discharge claim was brought by an employee who was fired for filing a workers' compensation claim - the plaintiff did not engage in whistleblowing. ${ }^{136}$ The court overruled summary judgment in favor of the employer and clarified the standard for granting summary judgment on a retaliatory discharge claim. ${ }^{137}$ Borrowing from retaliation claims brought under state anti-discrimination statutes, the court held that a plaintiff may rely on the same evidence used to establish her prima facie case to establish that the employer's stated reason for taking adverse action is pretextual. ${ }^{138}$ The court went on to note that an employer

133. See Zinn v. Am. Commercial Lines, ARB No. 10-029, 2012 WL 1143309, at *7 (Dep't of Labor Admin. Rev. Bd. Mar. 28, 2012) ("However, a temporal proximity of seven to eight months between protected activity and adverse action may be sufficient circumstantial evidence to prove that the protected activity contributed to the adverse action."). See also Vieques Air Link, Inc. v. U.S. Dep't of Labor, 437 F.3d 102, 109 (1st Cir. 2006) (holding that "the ALJ permissibly treated the temporal proximity between the reports and the suspensions as sufficient to show the requisite causal relationship").

134. Recent decisions under Sarbanes-Oxley take an even more employee-favorable approach, holding that after the plaintiff establishes a prima facie case, the burden of proof shifts to the employer and remains there to establish that the employer would have taken the action regardless of the whistleblowing behavior. See Zinn, 2012 WL 1143309, at *6. However, claims brought under Sarbanes-Oxley are subject to the burdens of proof established in the Wendell H. Ford Investment and Reform Act for the 21st Century (AIR 21). See 18 U.S.C. $\$ 1514$ A(b)(2)(C) (2012) (directing the use of 49 U.S.C. $\$ 42121)$. AIR 21 expressly provides that the employer must prove it would have taken the action regardless of the employee's protected activity by clear and convincing evidence. 49 U.S.C. $\$$ 42121(b)(2)(B)(ii) (2012). Most state whistleblower statutes do not have such a high standard for employers, making it questionable whether the Sarbanes-Oxley standard should be adopted. See, e.g., N.J. STAT. ANN. $\$ \$ 34.19-1$ to -14 (West 2012) (containing no burdenshifting scheme); TENN. CODE ANN. § 50-1-304 (2012); ARIZ. REV. STAT. ANN. § 23-1501 (2012).

135. No. 40647-1-II, 2012 WL 211654 (Wash. App. Jan. 24, 2012).

136. Id. at $* 2$.

137. Id. at *5-7.

138. Id. at *7 (citing Milligan v. Thompson, 42 P.3d 418, 423 (Wash. Ct. App. 2002)). 
stating conflicting reasons for taking the action is sufficient to survive summary judgment. ${ }^{139}$

Given the low win rates of plaintiffs in whistleblowing cases, it raises the question of whether the employee-favorable standard articulated by the Washington Court of Appeals would have been the same had the case involved whistleblowers instead of a worker's compensation claimant.

\section{Viewing the Evidence in a Light Unfavorable to Employees}

As for the evidentiary issue, Vanderlaan is also an example of how courts tend to consider the evidence in a light that is unfavorable to employees. In Vanderlaan, the court assessed the evidence-the plaintiff's purported failure to submit to a psychiatric evaluation and drug test - and considered whether the evidence warranted the plaintiff's termination. ${ }^{140}$ The court found that the plaintiff's evidence was insufficient to establish causation. ${ }^{141}$ Facially, perhaps, this evidence is insufficient. However, the court failed to mention any of the evidence that indicated that the defendant was requiring the plaintiff to submit to the exam and test in retaliation for engaging in protected activity. ${ }^{142}$ In other words, according to the plaintiff's evidence, the retaliation began with the employer requiring the employee to undergo these activities. Given the divergent evidence, summary judgment appears to have been inappropriate.

Another example of a court's employer-favorable viewpoint is seen in Prieskorn v. University of Michigan Health System. ${ }^{143}$ In Prieskorn, the plaintiff alleged that he was discharged for having complained of patient safety violations and time-card fraud. ${ }^{144}$ The trial court granted summary disposition to the employer, concluding that there was no genuine issue of material fact as to whether there was a causal

139. Id. (citing Renz v. Spokane Eye Clinic, P.S., 60 P.3d 106, 112 (Wash. Ct. App. 2002)).

140. Vanderlaan v. Mich. Med., P.C., No. 300660, 2012 WL 284580, at*3 (Mich. Ct. App. Jan. 31, 2012).

141. Id.

142. See id. See also Appellant's Brief on Appeal, Vanderlaan, 2012 WL 284580 (No. 300660), 2011 WL 762335, at *17-22 (discussing the psychiatric exam and facts indicating that the request was not justifiable). The court also stated that the plaintiff "inexplicably" refused to submit to a psychiatric exam, which the defendant scheduled with a doctor of defendant's choice and gave plaintiff only a 24 -hour notice. Vanderlaan, $2012 \mathrm{WL} 284580$, at $* 3$. It is difficult to imagine any person agreeing to such a requirement.

143. No. 298996, 2012 WL 205801 (Mich. Ct. App. Jan. 24, 2012).

144. Id. at $* 1$. 
connection between the employee's complaints and his termination. ${ }^{145}$ On appeal, the employee asserted that the timing of his termination combined with the fact that he had received a good employee evaluation suggested that his termination was due to his whistleblowing complaints. ${ }^{146}$ The appellate court disagreed. ${ }^{147}$ It focused on the letter terminating the plaintiff, which articulated other reasons for his firing. ${ }^{148}$ This, however, should not be sufficient to establish lack of causation as a matter of law; at best, it creates a second possible reason for the termination, and the determination of which is correct should be left to the fact-finder.

This is not to suggest that summary judgment is never properly granted. While it is impossible to determine as a matter of absolute certainty whether a decision is correct based on the records available, there are cases where summary judgment appears more appropriate than those described above. For instance, in Morales $v$. Waste Management of Alameda County it was undisputed that the plaintiff made statements suggesting that he might engage in violent conduct — using a gun - in the workplace. ${ }^{149}$ The threat rose to the level of concern that the police were called and a report was filed. ${ }^{150}$ These statements violated the defendant's zero tolerance policy on violence in the workplace, and the plaintiff was discharged. ${ }^{151}$

\section{Narrowly Interpreting Statutes and Common Law Doctrines}

In addition to granting summary judgment on a frequent basis to defendants, there were a few instances of courts finding against plaintiffs by narrowly interpreting whistleblower protection statutes. For example, in Prieskorn, the court effectively narrowed the scope of the protected conduct by determining that if the adverse employment action was based on a supervisor's dislike of any complaining, rather than reacting to the substance of the complaints, then the complaints were not protected

\footnotetext{
145. See id. Summary disposition is a mechanism to challenge the sufficiency of the pleadings and to obtain what amounts to summary judgment. It differs from the federal motion to dismiss because the court can consider depositions and other evidence beyond the complaint. Compare FED. R. CIV. P. 12(b)(6), with Mich. CT. R. 2.116(C)(10).

146. Prieskorn, 2012 WL 205801, at *3.

147. Id.

148. Id.

149. No. A131130, 2012 WL 243231, at *2 (Cal. Ct. App. Jan. 26, 2012).

150. Id. at $* 2$.

151. Id. at *1-2.
} 
activity. ${ }^{152}$ In that case, the plaintiff's deposition testimony suggested that the firing was because the plaintiff's supervisor was tired of hearing the plaintiff complain about a number of issues, some of which were protected and some of which were not. ${ }^{153}$ In other words, the court appeared to indicate that so long as the supervisor was upset about the complaining, not the substance of the complaints, it would not violate the whistleblower protection statute to fire the plaintiff.

The flaw in this reasoning is as follows. First, if the complaints were reports under the state's whistleblower protection statute and were part of the reason for the termination, then regardless of the employer's consideration of the substance of the complaint, the plaintiff was engaging in protected activity. ${ }^{154}$ This fits within the plain meaning of the statute. Furthermore, following the Prieskorn approach would allow employers to circumvent the purpose of the statute by having a policy of firing all employees who complain. ${ }^{155}$

The cases also suggest that courts are narrowly interpreting what constitutes a public policy sufficient to establish a common law claim for wrongful (or retaliatory) discharge in violation of public policy. For example, in Ulm v. Memorial Medical Center, the court determined that no such claim is viable when the employee seeking relief is responsible for ensuring compliance with the statute that is the source of public policy. ${ }^{156}$ Thus, where an employee complains about a company's noncompliance with a statutory command, so long as compliance falls within that employee's responsibilities, no wrongful discharge claim is

\section{2012 WL 205801, at*3.}

153. Id. at $* 3$ n. 2 .

154. See Мich. COMP. LAWS § 15.362 (2013) (stating that, "[a]n employer shall not discharge, threaten, or otherwise discriminate against an employee regarding the employee's compensation, terms, conditions, location, or privileges of employment because the employee, or a person acting on behalf of the employee, reports or is about to report, verbally or in writing, a violation or a suspected violation of a law or regulation or rule promulgated pursuant to law of this state, a political subdivision of this state, or the United States to a public body ..." (emphasis added)).

155. Cf. Collins v. Beazer Homes USA, Inc., 334 F. Supp. 2d 1365, 1380-81 (N.D. Ga. 2004) (stating that, under the Sarbanes-Oxley Act, where an employee made numerous complaints, some of which were protected and some of which were not, summary judgment was inappropriate because allowing an employer to rely upon the unprotected complaints would undermine the goals of the whistleblower protection provision).

156. 964 N.E.2d 632, 639 (Ill. App. Ct. 2012). For another similar example, see also Ainsworth v. Newmont Mining Corp., No. 56250, 2012 WL 987222, at *3 (Nev. Mar. 20, 2012) (holding that reports of illegal activity to a supervisor is not protected whistleblowing activity). On the other hand, one case in the sample came out against the job duties exclusion and noted that "the entire purpose of the [public policy] exception [to at-will employment] would be thwarted" if the exclusion were adopted. Bollinger v. Fall River Rural Elec. Coop., 272 P.3d 1263, 1272 (Idaho 2012). 
allowed. ${ }^{157}$ The court articulated its rationale as follows:

Whether plaintiff was adequately performing her job with respect to defendant's compliance with laws ... is more a dispute for the parties to resolve privately than a public matter justifying the courts' involvement on behalf of the citizenry ... even though the integrity of essential health information may have been at stake.

The court's decision suffers from two failings. First, its articulation of the issue-focusing on the plaintiff's job performance instead of whether the employee complained about non-compliance-is misleading. The issue of whether an employee was performing his or her job is separate from the inquiry into whether the employee was faced with the prospect of either personally violating the law or, through her job, having a company violate the law. If the employee is truly not performing her job properly, that inquiry would become a part of the court's analysis of whether the employer had a legitimate reason for taking adverse action against the employee. It should not be a part of the court's analysis of whether a plaintiff has identified an appropriate source of public policy. ${ }^{159}$ Second, if the integrity of essential health information is at stake, it is not merely a "private dispute" between the employer and the employee. Those whose health information is at risk are also interested parties, which brings the matter out of the purely private realm and into the public interest realm.

Another example of narrow interpretation of whistleblower protection is seen in one of the decisions in the sample that addressed the intent requirement for an employee engaging in protected behavior. In Ainsworth v. Newmont Mining Corp., the Nevada Supreme Court held that in order to be protected, an employee "must affirmatively decide to expose illegal or unsafe practices." 160 Employees, like the plaintiffs in Ainsworth, who report employer conduct without knowing it is illegal when they make the report are not protected under the common law wrongful discharge claim. ${ }^{161}$

In Ainsworth, one of the plaintiffs was speaking with the Nevada

157. See Ulm, 964 N.E.2d at 639. Essentially, this imports the job duties exclusion I analyzed in The Garcetti Virus, 80 U. CIN. L. REV. 137 (2011) into common law claims for wrongful discharge.

158. Ulm, 964 N.E.2d at 639.

159. For a detailed explanation of the flaws with the job duties exclusion, see Modesitt, supra note 157 .

160. No. 56250, 2012 WL 987222, at *2 (Nev. March 20, 2012).

161. Id. 
Department of Environmental Protection (NDEP) about a construction project. ${ }^{162}$ The NDEP asked the plaintiff when plans would be submitted for a "quench tank" that was required under the state's environmental protection laws. ${ }^{163}$ Plans for this quench tank were required to be filed with the NDEP before construction began. ${ }^{164}$ The plaintiff informed the NDEP that construction on the quench tank had already begun, not realizing at the time that the plans had to be filed before construction was underway. ${ }^{165}$ The plaintiff disclosed illegal activity but was not aware that the conduct was illegal, and she was allegedly fired for doing so. ${ }^{166}$ Where an employee exposes actual illegal conduct, not suspected illegal conduct, even unwittingly, it is a sufficiently important public interest that it should be protected. Indeed, it seems arguably more crucial to protect these disclosures than situations where an employee reasonably believes that the conduct is illegal but is mistaken - and these situations are frequently protected by courts. ${ }^{167}$ If the employee is wrong, but has a reasonable belief, there is no illegal conduct that needs to be exposed or remedied. However, if the employee is right, even if the employee did not intend to blow the whistle, there is still a direct social benefit to the disclosure of wrongdoing.

\section{Are Courts Hostile to Whistleblowers?}

One of the most disturbing findings of this research is the indication that whistleblowers in state court cases appear to be prevailing at a rate that is only somewhat higher than the rate of SOX whistleblowers. It was entirely unexpected, in part because Moberly's analysis of the reasons for the low win rates in SOX cases focused primarily on factors unique to Sarbanes-Oxley: narrow interpretations of the applicable statutes of limitations, narrow interpretations of the employers covered by the Act, narrow interpretations of the Act's protections, and misapplications of the employee-friendly burden of proof. ${ }^{168}$ Before

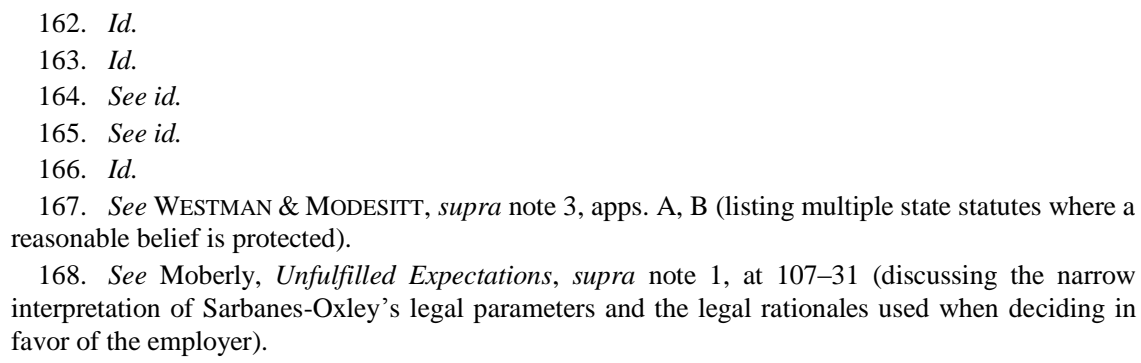


conducting the research, it was expected that, when not before a tribunal hampered in the manner Moberly articulates, whistleblowers would prevail at significantly higher rates than SOX whistleblowers.

Indeed, it was also anticipated that whistleblowers would prevail at rates higher than employment discrimination plaintiffs. Whistleblowers, it seemed, would be seen in a more positive light than employment discrimination plaintiffs because of the well-publicized failures of corporations to effectively police themselves ${ }^{169}$ and the media's positive portrayal of whistleblowers. Yet the similarity in outcomes seen in SOX cases and this research suggest there is some commonality in how decision-making parties view whistleblowers - and that the view is not positive.

A common theme that might account for courts' apparent hostility to employees in whistleblower cases is that courts dislike having to delve into the minutia of the reasons for an employee's termination. Corporate lawyers have used this by focusing attention on the business judgment rule, suggesting that so long as the corporation articulates a facially legitimate reason for taking adverse action against the plaintiff, courts should respect and not second guess the corporate judgment. ${ }^{170}$ As articulated in an appellate brief filed by management, "Courts do not sit as super-personnel departments reviewing the wisdom or fairness of the business judgments made by employers, except to the extent that those judgments involve intentional discrimination."171 Directly addressing the issue of pretext, one management attorney put it baldly, stating, "Plaintiff may not simply question, or second guess, the soundness of [the employer's] business judgment to show pretext.... '[A] fact-finder need not, and indeed should not, evaluate whether a defendant's stated purpose is unwise or unreasonable." 172 These quotes and this doctrine

169. See, e.g., Phil Angelides, Chairman, The Financial Crisis Inquiry Commission's Autopsy of Our Failed Financial System, Address at the University of Missouri-Kansas City Law Review Symposium: FCIC and the Crisis: Preventing the Next Financial Meltdown (Nov. 10, 2011), in 80 UMKC L. REV. 949, 954-57 (2012) (explaining financial regulation failures were caused by an incorrect belief that the financial industry could manage risks without a high level of public oversight); L. Randall Wray, Global Financial Crisis: Causes, Bail-Out, Future Draft, 80 UMKC L. REV. 1101, 1102 (2012) (discussing the failures of corporate governance caused by the move toward self-regulation).

170. See, e.g., Brief of Appellees Dawson Pub. Power Dist. and Robert A. Heinz, Teetor v. Dawson Pub. Power Dist., 808 N.W.2d 86 (Neb. Ct. App. 2012) (No. A-11-00170), 2011 WL 2617947 , at $* 3-5$ (articulating laws regarding employers' rights to terminate at-will employees for good cause).

171. Id. at *4 (citing Elam v. Regions Fin. Corp., 601 F.3d 873, 881-82 (8th Cir. 2010)).

172. Defendant-Appellee's Brief on Appeal, King v. Chrysler Grp. LLC, No. 301246, 2012 WL 
are misleading in the context of whistleblower claims where the plaintiff alleges pretext. The entire point of the plaintiff's argument is that the stated reason for the adverse employment action is not valid; the court or jury must assess the corporation's stated reasons and look behind the articulated rationale. Once the plaintiff establishes a prima facie case, there is sufficient evidence to justify disregarding the business judgment rule - it should have no application in this context.

However, this dislike of playing the role of a super-human resources department should, at worst, put whistleblowers in a position akin to employment discrimination plaintiffs. It fails to account for the lower success rates of whistleblowing plaintiffs. Is it merely because whistleblowers are still seen as snitches, despite the recently positive media portrayals? Is it because whistleblowing plaintiffs have personal characteristics that make them less likeable to judges? These questions are important because even if the legal standards are brought into alignment with causation in other contexts, if judges are predisposed against whistleblowers, a purely legal correction may not solve the problem.

\section{CONCLUSION}

When I undertook this research, I understood from practitioners that there was a sense that plaintiffs in whistleblowing cases do not fare particularly well. My findings are a testament to that notion. Plaintiffs in state court whistleblowing cases prevail at a rate well below that of torts plaintiffs and more akin to the whistleblower plaintiffs studied by Moberly under the Sarbanes-Oxley Act at the administrative level. The biggest single reason for the failure of plaintiffs appears to lie within the causation element of the claim. This research suggests that courts are denying claims based on employer-favorable legal standards as well as by considering the evidence in a light favorable to the employer. However, this is an initial review of a set of cases raising the issue of whether state courts are improperly denying relief to plaintiffs. It is not a definitive study. Review and analysis of the current causation legal standards that state courts across the country apply is necessary to determine whether this is a broad problem or one limited to the jurisdictions represented in the study.

164202 (Mich. Ct. App. Jan. 19, 2012) (No. 301246), 2011 WL 7627350, at*25 (quoting DeMarco v. Holy Cross High Sch., 4 F.3d 166, 170-71 (2d Cir. 1993) (citing Dubey v. Stroh Brewery Co., 462 N.W.2d 758 (Mich. Ct. App. 1990))). 